\title{
A new species of Melita Leach, 1814 (Amphipoda: Hadzioidea: Melitidae) from Patos Lagoon, southern Brazil
}

\author{
André R. Senna, Rayane Sorrentino, Angelina N. S. Machado and Paula Torrent \\ Centro Universitário de Volta Redonda (UniFOA), Curso de Ciências Biológicas. Av. Paulo Erlei \\ Alves Abrantes, 1.325, Prédio 1, Três Poços, 27240-560, Volta Redonda, Rio de Janeiro, Brazil. \\ E-mail: (ARS) senna.crustacea@gmail.com; ar.senna@hotmail.com
}

\section{Abstract}

A new species of the family Melitidae Bousfield, 1973, Melita petronioi sp. nov., is described with material collected from Patos Lagoon, coast of the Brazilian state of Rio Grande do Sul, southern Brazil. The new species is the unique species of Melita Leach, 1814 in Brazilian waters with urosomites 1 and 2 lacking spines, but urosomite 2 bearing two sets of dorsal stout setae, and the uropod 3 with the outer ramus 2-articulate. It is the first Melita species recorded to the southern region of the country.

Key words: Amphipod, melitid, Rio Grande do Sul, taxonomy

\section{Introduction}

The family Melitidae s.s. Bousfield, 1973 is composed by 39 genera distributed around the world (Lowry and Hughes, 2009; Senna and Serejo, in press). Amphipods of the superfamily Hadzioidea are very abundant and frequent in benthic samples. However, there are only six species of Melitidae recorded from Brazilian waters: Dulichiella anisochir (Krøyer, 1845); Cuneimelita danielle Senna and Serejo, 2012; Nuuanu peroa Senna and Serejo, in press; Melita orgasmos Barnard, 1940; M. mangrovi Oliveira, 1953; and M. lagunae Oliveira, 1953 (Senna and Serejo, 2012). One of these species, $M$. lagunae, has never been recorded after its original description. The other species, $M$. mangrovi, was recorded by Leite et al. (1980), from Ubatuba, São Paulo state, but this material seems to be lost now. There are two samples identified as $M$. mangrovi deposited at the Crustacea Collection of Museu Nacional (MNRJ 10679 and MNRJ 10401) from Lagoa de Saquarema, Rio de Janeiro state, and Ilha de Fortaleza, Pará state, Brazil. Those samples must be examined to confirm their identity. The type locality of this species, originally characterized by a mangrove habitat, beside the Guanabara Bay, were land filled in the 1960s by the Brazilian federal government for the urbanization of a poor community named Complexo da Maré (Azevedo et al., 2008).

The genus Melita was described for the first time by Leach (1814), being the species Cancer palmatus Montagu, 1804 its type species. After that, a lot of other species were described around the world to this genus, that nowadays groups about 55 brackish and shallow water marine species (Karaman, 1981; Jarret and Bousfield, 1996; Lowry and Sprinthorpe, 2005; 2009). Melita and related genera are Gondwana relict groups whose members are tropical and warm temperate, with relatively limited penetration into the North Atlantic and North Pacific regions (Jarret and Bousfield, 1996). 
According to Jarret and Bousfield (1996), the Melita species are grouped in two morphological groups: a "typical" group, with dorsal spines on urosome 1 , and other one "atypical", lacking dorsal spines on urosome 1. Additionally, Melita also could be divided in two other groups: the first one presenting dorsal stout setae on urosome 2 , and the other group with dorsal spines (Labay, 2003).

The new species described in this paper belongs to the group of species without spines on the urosome 1 and with stout setae on the urosome 2. It is the first species of Melita recorded to the Brazilian state of Rio Grande do Sul.

\section{Material and Methods}

The material examined was collected on drift algae in Ilha das Pombas, inside the Patos Lagoon, Rio Grande do Sul state, Brazil, in June 1999. The specimens were dissected under a stereoscopic microscope and their appendages and mouth parts were mounted in glycerol gel slides. Illustrations were made under an optic microscope with camera lucida and digitally prepared in Corel Draw X5, following an adapted protocol based on Coleman (2003). All the type material is preserved in ethanol $70 \%$ and it is housed at the Crustacea Collection of the Museu Nacional, Universidade Federal do Rio de Janeiro (MNRJ). The setal/spine classification adopted in this paper follows Watling (1989). Nomenclature of gnathopod palm is based on Poore and Lowry (1997).

The setal formulae presented in the description and in the key, are related to the number of stout setae distributed along the outer margin of the outer ramus of uropod 3 , and the sequence is from the proximal to the distal part of the article. The following abbreviations are used in the figures: $\mathrm{Hd}$, head; A1-2, antennae 1-2; Md, mandible; Mx1-2, maxillae 1-2; UL, upper lip; LL, lower lip; Gn1-2, gnathopods 1-2; P3-7, pereopods 3-7; Ep1-3, epimeral plates 1-3; Ur1-3: urosomites
1-3; U1-3, uropods 1-3; T, telson; acfl: accessory flagelum; r, right; 1 , left.

Results

\section{Systematics}

Order Amphipoda Latreille, 1816

Suborder Gammaridea Latreille, 1802

Superfamily Hadzioidea Karaman, 1943

Family Melitidae s.s. Bousfield, 1973

Genus Melita Leach, 1814

Type species

Cancer palmatus Montagu, 1804

Species group of Melita lacking dorsal spines on urosomite 1 .

Melita awa Barnard, 1972a; M. alluaudi Ledoyer, 1982; M. almagosa Sawicki and Holsinger, 2005; M. bulla G. Karaman, 1978; M. coroninii Heller, 1866; M. elongata Sheridan, 1980; $M$. inaequistyla (Dana, 1852); M. intermedia Sheridan, 1980; M. laevidorsum Stephensen, 1944; M. lagunae Oliveira, 1953; M. longisetosa Sheridan, 1980; ?M. matilda Barnard, 1972b; M. mangrovi Oliveira, 1953; M. myersi G. Karaman, 1987; M. nitida Smith, 1873; M. nitidaformis Labay, 2003; $M$. nitidula Ruffo, 1958; M. oba Barnard, 1972b; M. pahuwai Barnard, 1970; M. petronioi sp. nov.; $M$. sampsonae Lowry and Springthorpe, 2009; M. valesi S. Karaman, 1955; M. zeylanica Stebbing, 1904; M. zeylanica kauerti Barnard, $1972 b$.

Melita petronioi sp. nov.

(Figs. 1-3)

Material examined: Holotype: 1 male, $7.3 \mathrm{~mm}$, in glycerol gel slides, dissected and drawn, Ilha das Pombas, Patos Lagoon, Rio Grande do Sul state, Brazil, R. A. Aquino col., 07 June 1999, on drift algae, MNRJ 23144. Paratypes: 6 males, 8 ovigerous females, and 1 juvenile, in ethanol 70\%, Ilha das Pombas, Patos Lagoon, Rio Grande do Sul state, Brazil, R. A. Aquino col., 07 June 1999, on drift 
algae, MNRJ 23145.

Etymology: This new species is dedicated to Dr. Petrônio Alves Coelho, professor of the Universidade Federal de Pernambuco, a great researcher on decapod crustaceans, and an inspiration for many of us.
Diagnosis: Antenna 2, article 4 of peduncle subequal in length to article 5 . Gnathopod 1, palm nearly transverse, posterodistal margin well produced. Urosomites lacking posterodorsal spines, urosomite 2 with two sets of three small stout setae on the posterodorsal margin. Uropod 3,

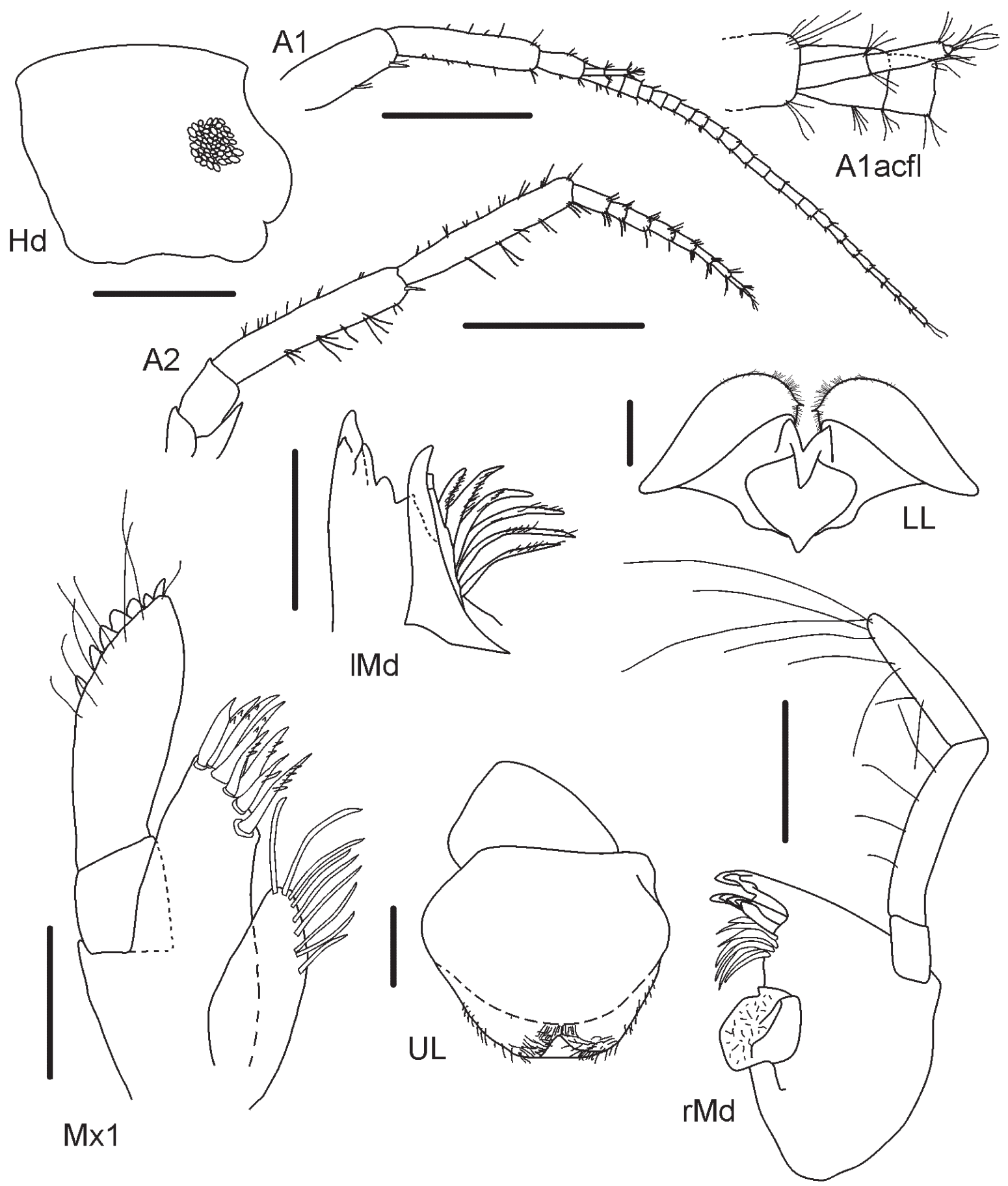

Figure 1. Melita petronioi sp. nov., holotype, male, $7.3 \mathrm{~mm}$, Patos Lagoon, Rio Grande do Sul state, Brazil, 07 June 1999, on drift algae, MNRJ 23144. Scale bars: $1.0 \mathrm{~mm}$ for A1-2; $0.5 \mathrm{~mm}$ for Hd; $0.2 \mathrm{~mm}$ for rMd; $0.1 \mathrm{~mm}$ for the remainder. 
outer ramus 2-articulate, outer margin bearing six stout setae equally spread, article 2 vestigial, reduced to a rounded tip. Telson slightly wider than long, deeply cleft, apically subacute, with three stout setae on the inner margin and one stout seta on the outer margin, in each lobe.

Description: Based on holotype male (MNRJ 23144). Head: slightly longer than
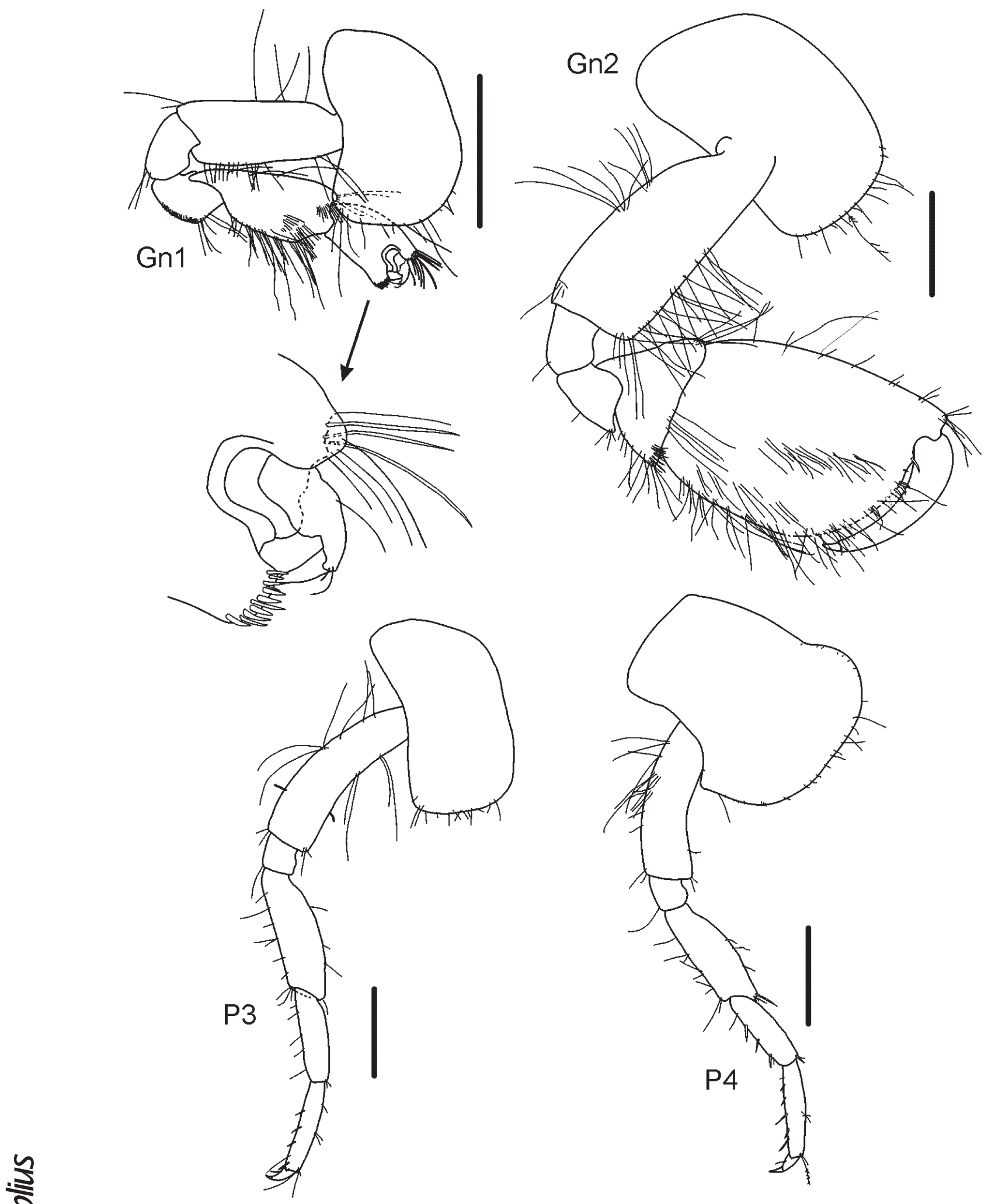

Figure 2. Melita petronioi sp. nov., holotype, male, $7.3 \mathrm{~mm}$, Patos Lagoon, Rio Grande do Sul state, Brazil, 07 June 1999, on drift algae, MNRJ 23144. Scale bars: $0.5 \mathrm{~mm}$. 

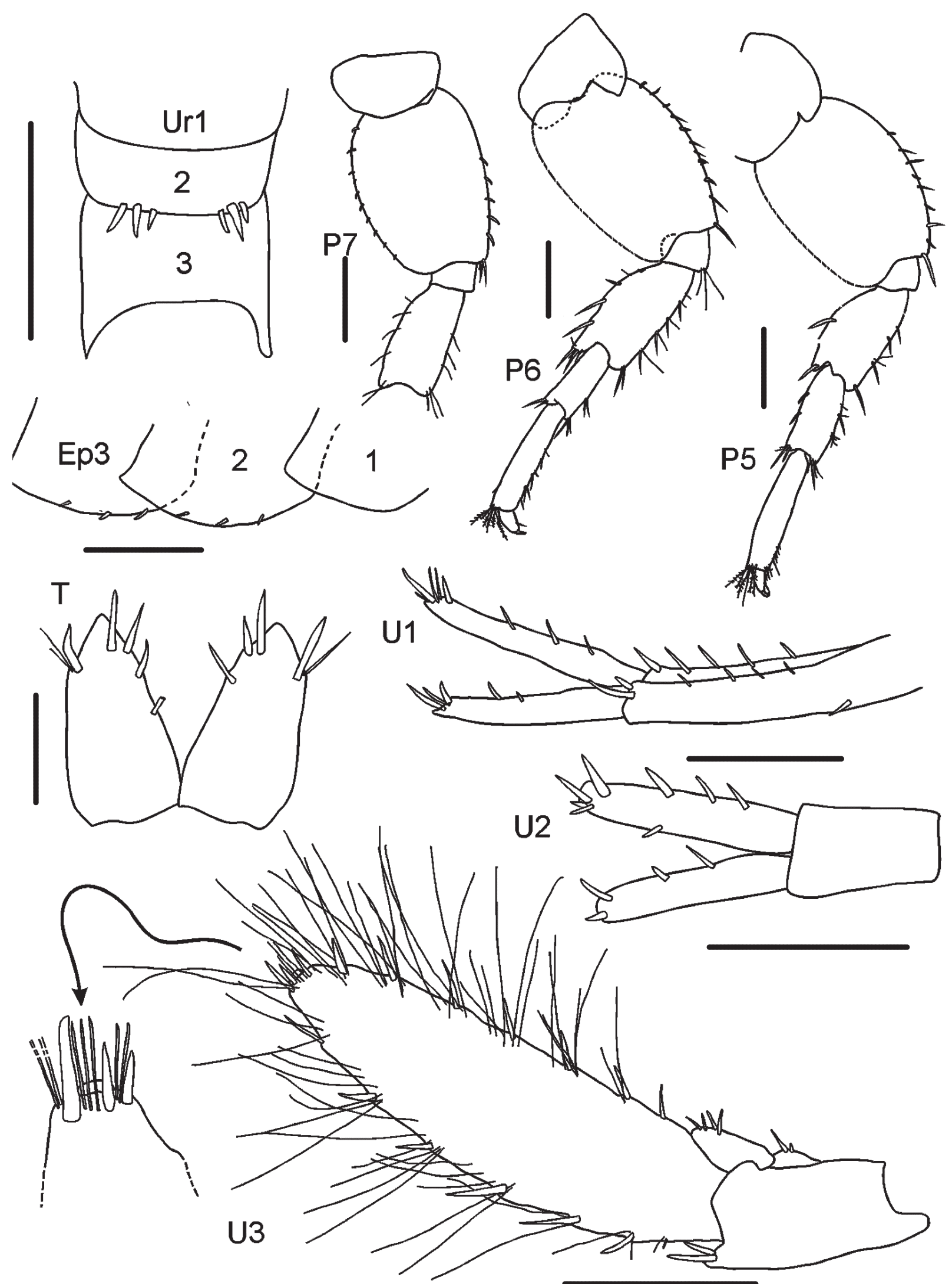

Figure 3. Melita petronioi sp. nov., holotype, male, $7.3 \mathrm{~mm}$, Patos Lagoon, Rio Grande do Sul state, Brazil, 07 June 1999, on drift algae, MNRJ 23144. Scale bars: $0.2 \mathrm{~mm}$ for T; $0.5 \mathrm{~mm}$ for the remainder. 
deep; eyes present; lateral cephalic lobe rounded; anteroventral notch present. Antenna 1 slightly elongate, about 1.25 times antenna 2 ; peduncle article 1 about 3 times longer than wide, anteroventral corner with a stout seta; article 2 slender, about 1.25 times article 1; flagellum elongate, with 24 articles; accessory flagellum 3-articulate, article 3 reduced, surpassing article 2 of primary flagellum. Mandible, molar triturative; incisor and lacinia mobilis multi-cuspidate; palp 3-articulate, article 1 twice longer than wide, distoventral spine absent, article 2 about 3.3 times longer than article 1 and 5 times longer than wide, ventral margin setose, article 3 retolinear, about 0.8 times the article 2 length, ventrally and apically setose. Maxilla 1, inner plate oval, slightly elongate, inner margin setose; outer plate, apical margin with eight multi-cuspidate stout setae; palp 2-articulate, article 2 distally setose and spinose. Upper lip rounded, apically notched and setose. Lower lip, inner lobe well developed; outer lobes densely setose, bearing a small spine innerly each one. Maxilla 2 and maxilliped with basic characters for the genus.

Gnathopod 1, coxa about 1.6 times longer than wide, anterior margin convex, ventral margin setose; basis subrectangular, about 2.6 times longer than wide, anterior margin distally setose, posterior margin with four long slender setae; ischium about 1.4 times longer than wide; merus trapezoid shaped, posterior margin slightly convex, minutely setose; carpus elongate, subrectangular, about 2.3 times longer than wide, posterior margin densely setose; propodus subrectangular, about twice longer than wide, and about 0.4 times the carpus length, anterior margin convex, palm nearly transverse, strongly concave on the inner face of the propodus, posterodistal margin well produced, covered by several small scales; dactylus strong, curved, with a slender seta on the outer margin, apical nail present. Gnathopod 2, coxa about 1.5 times longer than wide, anterior margin convex, ventral margin setose; basis subrectangular, about twice longer than wide, anterior margin densely setose; merus subrectangular, posterodistal corner produced and subacute; carpus subtriangular, slightly wider than long, posterior margin setose; propodus suboval, robust, posterior margin densely setose, inner face with some rows of slender setae, palm acute, defined by two small stout setae, margin bearing several small stout setae and other one displaced near dactylus articulation; dactylus stout, curved, shorter than palm, apical nail present. Pereopod 3, coxa about twice longer than wide, anterior margin convex, ventral margin with small slender setae; basis, slightly curved, about 4 times longer than wide, anterior margin with two sets of long slender setae, posterior margin, first half with six slender setae; merus suboval, about 3 times longer than wide, anterior margin straight; carpus subrectangular, about 0.7 times the merus length, anterior margin setose, posterior margin naked; propodus slender, about as long as carpus, anterior margin bearing four stout setae; dactylus curved, stout, anterior margin with a stout seta, apical nail present. Pereopod 4 similar to pereopod 3, but coxa 4 with posteroventral lobe present, subquadrate. Pereopod 5, coxa bilobate, two lobes separated by a deep notch, anterior lobe rounded, naked; basis about 1.6 times longer than wide, slightly expanded posteriorly, anterior margin bearing eight small stout setae, anteroventral corner with one long stout seta; merus, about twice longer than wide, posterior margin convex, with four curved stout setae; carpus subrectangular, about twice longer than wide, anterior and posterior margins with two stout setae each; propodus slender, about 4.5 times longer than wide and 1.4 times longer than carpus, anterior and posterior margins without stout setae, posterodistal corner with a row of plumose setae; dactylus stout, curved, apical nail present. Pereopod 6, coxa bilobate, anterior lobe ventrally subacute, anterior margin almost straight, posterior lobe shallow and subquadrate; basis slightly expanded posteriorly, about 1.7 times longer than wide, anterior margin bearing ten small stout setae, anteroventral corner with one long stout seta; merus, about twice longer than wide, posterior margin convex, with three curved stout setae; carpus subrectangular, about three times longer 
than wide; propodus slender, about 5.5 times longer than wide and 1.6 times longer than carpus, anterior and posterior margins without stout setae, posterodistal corner with a row of plumose setae; dactylus stout, curved, apical nail present. Pereopod 7, coxa suboval, about 1.7 times longer than deep, anteroventral corner defined, posteroventral margin rounded; basis posteriorly expanded, anterior margin with five small stout setae, posterior margin with ten small stout setae, anteroventral corner with two stout setae; merus about twice longer than wide, anterior margin with three stout setae, posterior margin convex, with four stout setae, anteroventral and posteroventral corners with two stout setae each.

Epimeral plate 1 subquadrate, ventral and posterior margins naked. Epimeral plate 2 subquadrate, ventral margin with three small stout setae, posteroventral corner weakly produced, subacute. Epimeral plate 3 subquadrate, ventral margin with three small stout setae, posteroventral corner not produced. Urosomites 1 to 3 lacking posterodorsal spines. Urosomite 2 with two sets of three small stout setae on the posterodorsal margin. Uropod 1, peduncle elongate, 5.5 times longer than wide, dorsally setose, basofacial stout seta present; inner ramus slightly longer than outer, about 0.8 times the peduncle length, dorsal margin with three setae, apex subacute, bearing a set of two stout and three slender setae; outer ramus with two small setae dorsally, apex subacute, bearing a set of two stout and one slender seta. Uropod 2 short, peduncle subrectangular, about 1.8 times longer than wide, naked; rami subequal in length, about 1.2 times longer than peduncle. Uropod 3, peduncle about twice longer than wide, with stout setae on the posteroventral corner; inner ramus reduced, wedge-shaped, bearing four distodorsal setae; outer ramus 2-articulate, outer and inner margin densely setose, outer margin bearing six stout setae equally spread (1-1-1-1-1-1), article 2 reduced to a rounded tip. Telson slightly wider than long, deeply cleft, apically subacute, with three stout setae on the inner margin and one stout seta on the outer margin, on each lobe.
Geographic distribution: Known only from the type locality, Patos Lagoon, Rio Grande do Sul state, southern Brazil (Fig. 4).

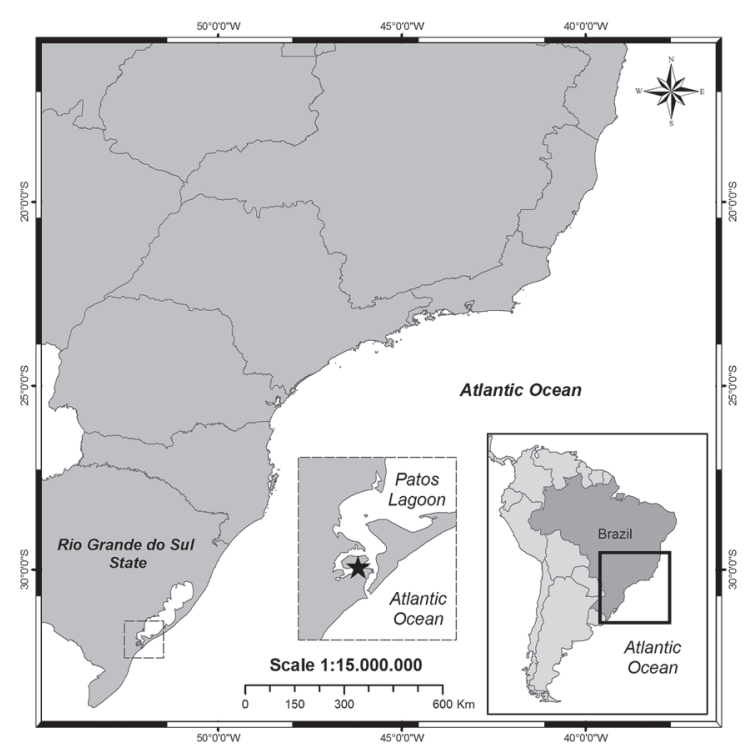

Figure 4. Melita petronioi sp. nov., type locality, Ilha das Pombas, Patos Lagoon, Rio Grande do Sul state, Brazil. Distribution map made by Danielle P. Cintra.

\section{Discussion}

Melita petronioi sp. nov. belongs to the group of atypical species, cited by Jarret and Bousfield (1996), and formed by species without dorsal spines on urosome 1. It presents abdominal segments weakly armed dorsally, like M. koreana Stephensen, 1944, M. laevidorsum Stephensen, 1944, and M. nitidaformis Labay, 2003, all of them from the Asia Far East (Labay, 2003). The new species differs from $M$. nitidaformis by the shape of the propodus of gnathopod 2, with anterior and posterior margins subparallel, and the weakly developed posteroventral lobe on pereopods 5-7. It also differs from $M$. koreana by lack spines on the dorsal surface of urosomite 2 , and differs from $M$. laevidorsum by the posteroventral corner of epimeral plate 3 subquadrate.

At the same time, it is part of the group with the uropod 3 outer ramus 2-articulate, like M. plumosa Zeidler, 1989, from the northern New South Wales, M. quadridentata 
Yamato, 1990, from the Seto Inland Sea, Japan, or M. almagosa Sawicki and Holsinger, 2005, from subterranean groundwaters in Guam, eastern Philippine Sea, North Pacific Ocean. However, the second article present in the new described species is very shorter than in the cited 2-articulate species, reduced to a rounded tip, while these species have well developed second article. Karaman (1981) established the new genus Abludomelita supported in two plesiomorphic characters, one of them the 2-articulate outer ramus of uropod 3, such as shown in $M$. petronioi sp. nov. However, some authors, as Zeidler (1989), Yamato (1990), and Jarret and Bousfield (1996), do not recognize this criteria to define the genus Abludomelita, and keep several species with 2-articulate uropod 3 in the genus Melita. For the same reason, the subterranean freshwater genus Paraniphargus Tattersall, 1925 was synonymized with Melita by Sawicki et al. (2005), as suggested 74 years before by Schellenberg (1931). Abludomelita is considered a valid genus, but the new species described here is clearly located in the genus Melita.

Regarding the other three species of Melita recorded from Brazilian waters, one of them, $M$. orgasmos, presents a dorsal spine on the urosomite 1 , while the other two species, $M$. lagunae and $M$. mangrovi, also lack abdominal dorsal spines, like the new species. Melita mangrovi presents two small setae dorsally on the urosome 2, while $M$. petronioi sp. nov. bears two sets of three small setae. On the other hand, seems that $M$. lagunae do not present these setae on the urosome 2 , as shown in the original description (Oliveira, 1953). It is not easy to discuss about these two species because the descriptions made by Oliveira (1953) were not very detailed, as well as their illustrations. However, is possible to observe in Oliveira's illustrations that these two species present the uropod 3 with outer ramus 1 -articulate. The other species recorded from Brazil, M. orgasmos, also presents outer ramus 1-articulate. Besides that, $M$. orgasmos presents epimeral plate 3 with posteroventral corner acutely produced, while the new species presents the epimeral plate 3 subquadrate and unproduced. Ledoyer (1979) defines the distribution of $M$. orgasmos being South Africa, India, and Indonesia. In fact, this species was recorded from São Paulo state coast by Wakabara et al. (1991) based in a faunistic study, without any description or illustration of the specimens. This material needs a revaluation to confirm its taxonomic identity. Thus, Melita petronioi sp. nov. can be distinguished from the other Brazilian species, being the unique presenting uropod 3 with 2-articulate outer ramus.

Additional comment: All examined specimens are infested with epibiont ciliates. Several crustacean groups, including amphipods, are found to be hosts (basibionts) of epibiont ciliates (Fernandez-Leborans et al., 2012). The epibiont ciliate species found attached to the examined material will be described in a subsequent publication.

\section{Identification key to species of Melita from Brazilian waters}

1. Antenna 1, articles 4 and 5 of peduncle subequal in length; urosomites 1 and 2 with small spines or stout setae on the posterodorsal margin...................................................... 2

- Antenna 1, articles 4 and 5 of peduncle unequal in length; urosomites 1 and 2 lackingdorsal spines................................... 3 2. Gnathopod 1, palm slightly obtuse, posterodistal margin weakly produced; urosomites 1 and 2 with a small posterodorsal spine each; uropod 3, outer ramus 1-articulate ...................... Melita orgasmos Barnard, 1940 - Gnathopod 1, palm nearly transverse, posterodistal margin strongly produced; urosomites 1 and 2 lacking spines, urosomite 2 with two sets of three small stout setae on the posterodorsal margin; uropod 3, outer ramus 2-articulate .............. Melita petronioi sp. nov. 3. Antenna 2, article 4 of peduncle shorter than the article 5; urosomite 2 with two small stout setae dorsally; uropod 3, outer ramus, outer margin with four sets of stout setae (11-4-4) ............Melita mangrovi Oliveira, 1953 
- Antenna 2, article 4 of peduncle longer than the article 5; urosomite 2 without stout setae dorsally; uropod 3, outer ramus, outer margin with six pairs of stout setae (2-2-2-2-22).................... Melita lagunae Oliveira, 1953

\section{Acknowledgments}

Digital illustrations were made in the Computer Laboratory of the Centro Universitário de Volta Redonda (UniFOA). The distribution map was made by Danielle P. Cintra, from UniFOA and Instituto de Geociências, Universidade Federal do Rio de Janeiro (IGEO-UFRJ). This study was financially supported in part by Coordenação de Aperfeiçoamento de Pessoal de Nível Superior (CAPES) and Fundação Carlos Chagas Filho de Amparo à Pesquisa do Estado do Rio de Janeiro (FAPERJ). One of the authors (RS) received Scientific Initiation scholarship (Proc. No. 104.565/2011), provided by Núcleo de Pesquisa do Centro Universitário de Volta Redonda (NUPE-UniFOA), which also provided financial support to carry out this project. The authors are grateful to Dr. Vjacheslav S. Labay and other anonymous referee by their valuable comments in the manuscript. We also thank Dr. Cristiana Serejo and Fabio Mauro for the help and support in the Crustacea Collection of Museu Nacional.

\section{References}

Azevedo, N.; Cortes, B.A. and Sá, M.R. 2008. Um caminho para a ciência: a trajetória da botânica Leda Dau. História, Ciências, Saúde - Manguinhos, 15 (suplemento): 209-229.

Barnard, J.L. 1970. Sublittoral Gammaridea (Amphipoda) of the Hawaiian Islands. Smithsonian Contributions to Zoology, 34: 1-286.

Barnard, J.L. 1972a. Gammaridean Amphipoda of Australia. Part I. Smithsonian
Contributions to Zoology, 103: 1-333.

Barnard, J.L. 1972b. The Marine fauna of New Zealand. Algae living littoral Gammaridea (Crustacea Ampbpoda). New Zealand Oceanographic Institute Memoirs, 62: 1-216.

Coleman, C.O. 2003. "Digital inking": How to make perfect line drawings on computers. Organisms, Diversity and Evolution, 3(14): $1-14$.

Dana, J.D. 1852. Conspectus Crustaceorum. Proceedings of the American Academy of Arts and Science, 2: 201-220.

Fernandez-Leborans, G.; Chatterjee, T. and Grego, M. 2012. New records of epibiont ciliates (Ciliophora) on Harpacticoida (Copepoda, Crustacea) from the Bay of Piran (Gulf of Trieste, Northern Adriatic). Cahiers de Biologie Marine, 53(1): 53-63.

Heller, C. 1866. Beiträge zur näheren Kenntnis der Amphipoden des Adriatischen Meeres. Denkschriften / Akademie der Wissenschaften in Wien, MathematischNaturwissenschaftliche Klasse, 26: 1-62.

Jarret, N.E. and Bousfield, E.L. 1996. The amphipod superfamily Hadzioidea on the Pacific coast of North America: family Melitidae. Part I. The Melita group: systematic and distributional ecology. Amphipacifica, 2(2): 3-74.

Karaman, G.S. 1978. On two Melita species (Fam. Gammaridae) from the Mediterranean Sea, M. bulla n. sp. and $M$. valesi S. Kar. 1955. Bollettino del Museo Civico di Storia Naturale di Verona, 5: 221237.

Karaman, G.S. 1981. Redescription of Melita planaterga Kunkel, 1910 from Bermuda with revision of the genera Melita Leach and Abludomelita n. gen. Poljoprivreda I Sumarstvo, Titograd, 27(1): 29-50.

Karaman, G.S. 1987. A new species of genus Melita Leach (Fam. Melitidae) from Bermuda and Fiji Islands. Contribution to the knowledge of the Amphipoda, 173. Glasnik Prirodnjackog Muzeja u Beogradu, B 42: 19-35.

Karaman, S. 1955. Uber einige Amphipoden des Grundwassers der Jugoslavischen Meereskuste. Acta Musei Macedonici 
Scientiarum Naturalium, 2: 223-242.

Labay, V.S. 2003. A new species of Melita Leach (Amphipoda: Melitidae) from oligosaline waters of Russian Far East. Zootaxa, 356: 1-8.

Leach, W.E. 1814. Crustaceology. The Edinburgh Encyclopaedia, 7: 383-437.

Ledoyer, M. 1979. Expédition Rumphius II (1975): Crustacés parasites, commensaux, etc. In: T. Monod and R. Serène (eds), Crustaces amphipodes gammariens. Bulletin du Muséum national d'Histoire naturelle, série 4, 1: 137-181.

Ledoyer, M. $\quad 1982 . \quad$ Crustacés amphipodes gammariens familles des Acanthonotozomatidae à Gammaridae. Faune de Madagascar, 59(1): 1-598.

Leite, F.P.P., Tararam, A.S. and Wakabara, Y. 1980. Composição de distribuição da fauna Gammaridea na região da Enseada da Fortaleza-Ubatuba, Estado de São Paulo. Boletim do Instituto Oceanográfico, 29(2): 297-299.

Lowry, J.K. and Hughes, L.E. 2009. Maeridae, the Elasmopus group. p. 643-702. In: J.K. Lowry and A.A. Myers (eds), Benthic Amphipoda (Crustacea: Peracarida) of the Great Barrier Reef, Australia. Zootaxa, 2260: 1-930.

Lowry, J.K. and Springthorpe, R.T. 2005. New and little-known melitid amphipods from Australian waters (Crustacea: Amphipoda: Melitidae). Records of the Australian Museum, 57(2): 237-302.

Lowry, J.K. and Springthorpe, R.T. 2009. Melitidae, the Melita group. p. 718-735. In: J.K. Lowry and A.A. Myers (eds), Benthic Amphipoda (Crustacea: Peracarida) of the Great Barrier Reef, Australia. Zootaxa, 2260: 1-930.

Montagu, G. 1804. Description of several marine animals found on the south coast of Devonshire. Transactions of the Linnean Society of London, 7: 61-85, pls. 6-7.

Oliveira, L.P.H. 1953. Crustacea Amphipoda do Rio de Janeiro. Memórias do Instituto Oswaldo Cruz, 51: 289-376.

Poore, A.G.B. and Lowry, J.K. 1997. New ampithoid amphipods from Port Jackson,
New South Wales, Australia (Crustacea: Amphipoda: Ampithoidae). Invertebrate Taxonomy, 11: 897-941.

Ruffo, S. 1958. Amphipodes terrestres et des eaux continentales de Madagascar, des Comores et de la Reunion. Mémoires de l'Institute Scientifique de Madagascar, Série A, 12: 35-66.

Sawicki, T.R..; Holsinger, J.R. and Iliffe, T.M. 2005. New species of amphipod crustaceans in the genera Tegano and Melita (Hadzioidea: Melitidae) from subterranean groundwaters in Guam, Palau, and the Philippines. Journal of Crustacean Biology, 25(1): 49-74.

Schellenberg, A. 1931. Amphipoden der Sunda-Expeditionen Thienemann und Rensch. Archiv fuer Hydrobiologie, Supplement 8: 493-511.

Senna, A.R. and Serejo, C.S. 2012. A new genus and species of Melitidae (Crustacea: Amphipoda: Hadzioidea) from Brazilian waters. Zootaxa, 3433: 60-68.

Senna, A.R. and Serejo, C.S. in press. A new species and first record of the genus Nuuanu (Amphipoda: Hadzioidea: Melitidae) from Brazilian waters. Zoosystematics and Evolution.

Sheridan, P.F. 1980. Three new species of Melita (Crustacea: Amphipoda), with notes on the amphipod fauna of the Apalachicola estuary of northwest Florida. Northeast Gulf Science, 3(2): 60-73.

Smith, S.I. 1873. Crustacea ex. Isopoda. p. 295-778. In: A.E. Verrill (ed), "Report on the invertebrate animals of Vineyard Sound”. Commission Fish \& Fisheries. Part 1.

Stebbing, T.R.R. 1904. Gregarious Crustacea of Ceylon. Spolia Zeylanica, 2: 1-29.

Stephensen, K.H. 1944. Some Japanese Amphipods. Videnskabelige Meddelser fra Dansk naturhistorisk Forening i Kobenhavn, 108: 25-88.

Wakabara, Y.; Tararam, A.S.; Valério-Berardo, M.T. and Duleba, W. 1991. Gammaridean and Caprellidean fauna from Brazil. Hydrobiologia, 223: 69-77.

Watling, L. 1989. A classification of crustacean 
setae based on the homology concept. p. 15-26. In: B.E. Felgenhauer, A.B. Thistle and L. Watling (eds), Crustacean Issues. Functional Morphology of Feeding and Grooming in Crustacea, Vol. 6. Rotterdam, A.A. Balkema.

Yamato, S. 1990. Two new species of the genus Melita (Custacea: Amphipoda) from shallow waters of the Seto Inland Sea of Japan. Publications of the Seto Marine Biology Laboratory, 34(4/6): 149-165.

Zeidler, W. 1988 (1989). A new species of Melita (Crustacea: Amphipoda: Melitidae) from northern New South Wales with a note on the genus Abludomelita Karaman, 1981. Proceedings of the Linnean Society of the New South Wales, 110(4): 327-338. 